Vol 1 No 22020 Desember 2020

Jurnal AlphaEuclidEdu

Received: 24/10/2020; Revised: 30/11/2020; Accepted: 06/12/2020

\title{
TANTANGAN BELAJAR MATEMATIKA DALAM MATERI ARITMATIKA SOSIAL PADA PESERTA DIDIK BERKEBUTUHAN KHUSUS
}

\author{
${ }^{1}$ Wulandari, Adinda Cintya, ${ }^{2}$ Sugiatno, ${ }^{3}$ Bistari \\ 1,2,3 Pendidikan Matematika FKIP Universitas Tanjungpura Pontianak \\ Email: adindacintyawulandari@gmail.com
}

\begin{abstract}
Advantages in mathematics education require high equality and strong support for all students and students from different backgrounds both social life and those in remote areas need to get equality in mathematics education. Learning challenges are basically caused by the emergence of students' obstacles in learning that students feel in the process of teaching and learning mathematics so that students are slow or unable to achieve their learning goals properly. In order to be able to spur the success of the mathematics learning process for SLB students, therefore we need basic facilities and infrastructure or supporting student success. The research aims to explore the cognitive factors that cause the challenges of learning mathematics in social arithmetic material in students with special needs. Descriptive method is used in this research. in the research subject consisted of 4 students of class VIII Extraordinary Middle School - B Dharma Asih Pontianak. The data obtained include student learning outcomes in social arithmetic material and student interviews. The results showed that $75 \%$ have not been able to work on social arithmetic problems so that the cognitive factors that cause the more dominant mathematical learning challenges affecting the four subjects are understanding and application.

Keywords: Children with Special Needs, Learning Challenges, Social Arithmetic.
\end{abstract}

\section{Pendahuluan}

Menurut para ahli di National Council Of Teachers Of Mathematics [NCTM] (2000: 12) menyatakan bahwa kelebihan dalam pendidikan matematika membutuhkan harapan/ ekspektasi yang tinggi serta dukungan/motivasi yang kuat bagi semua siswa. Siswa dengan latar belakang kehidupan sosial yang berbeda maupun yang tinggal di pelosok perlu mendapatkan kesetaraan pendidikan matematika. Kesempatan dan dukungan yang cukup harus dimiliki Semua siswa untuk belajar matematika tanpa memandang ciri-ciri persoalan, latar belakang atau hambatan fisik. pendidikan SLB adalah lembaga pendidikan yang tujuannya untuk membantu siswa yang mempunyai kelainan mental maupun fisik, perilaku dan interaksi sosial supaya bisa mengembangkan sikap, pengetahuan dan keterampilan yang dimilikinya sebagai pribadi maupun anggota masyarakat untuk mendapatkan hubungan timbal balik terhadap lingkungan sosial, budaya dan alam sekitar serta dapat melanjutkan pendidikan/ mengembangkan kemampuannya dalam dunia pekerjaan. Jenis pendidikan Luar Biasa mencakup: SLB-A untuk peserta didik Tunanetra, SMPLB-B untuk peserta didik Tunarungu, SLB-C untuk peserta didik Tunagrahita, SLB-D untuk peserta didik Tunadaksa, SLB-E untuk peserta didik Tuna Laras, dan SLB-G untuk peserta didik Tuna Ganda. Pada saat peneliti melaksanakan Program pra riset di SMPLB-B Dharma Asih Pontianak, peneliti melakukan observasi partisipatif di kelas 8 pada pembelajaran matematika dengan cara memberikan soal Aritmatika Sosial yang sudah lewat kepada 
Vol 1 No 22020 Desember 2020

Jurnal AlphaEuclidEdu

siswa di kelas tersebut. Hasil pengamatan peneliti mengenai soal yang diberikan kepada siswa ternyata siswa belum mampu mengerjakan soal secara tepat meskipun terdapat beberapa siswa yang mampu mengerjakan soal dengan benar.

Selain memberikan soal, peneliti juga mewawancara satu orang guru matematika yang mengajar siswa pada kelas tersebut dan fakta lapangan guru mengalami hambatan pada proses mengajar dikarenakan guru belum mampu menguasai bahasa isyarat yang digunakan siswa dalam sehari-hari meskipun guru yang ada di sekolah tersebut diberi buku panduan belajar bahasa isyarat. Anak tersebut membutuhkan metode, material, pelayanan dan peralatan yang khusus agar dapat mencapai perkembangan yang optimal. Karena anak-anak tersebut mungkin akan belajar dengan kecepatan yang berbeda dan juga dengan cara yang berbeda pula. Walaupun mereka memiliki potensi dan kemampuan yang berbeda dengan anak-anak secara umum, mereka harus mendapat perlakuan dan kesempatan yang sama. Hal ini dapat dimulai dengan cara penyebutan terhadap anak dengan kebutuhan khususTantangan belajar Pada dasarnya disebabkan karena adanya hambatan belajar yang dialami siswa dalam pembelajaran matematika sehingga siswa lambat atau tidak dapat mencapai tujuan pembelajaan dengan baik, bukan karena kebodohan siswa atau ketidakmampuannya dalam belajar, tetapi terdapat kondisis-kondisi tertentu yang membuat siswa tidak siap untuk belajar. Sekolah Luar Biasa (SLB) adalah sekolah khusus bagi anak usia sekolah yang memiliki "kebutuhan khusus".

Menurut Petunjuk Pelaksanaan Sistem Pendidikan Nasional Tahun 1993, Lembaga pendidikan SLB adalah lembaga pendidikan yang bertujuan membantu peserta didik yang menyandang kelainan fisik dan mental, perilaku dan sosial agar mampu mengembangkan sikap, pengetahuan dan keterampilan sebagai pribadi maupun anggota masyarakat dalam mengadakan hubungan timbal balik dengan lingkungan sosial, budaya dan alam sekitar serta dapat mengembangkan kemampuan dalam dunia kerja atau mengikuti pendidikan lanjutan. Satuan SLB disebut juga sistem segregasi yaitu sekolah yang dikelola berdasarkan jenis ketunaan namun terdiri dari beberapa jenjang. Adapun satuan pendidikan bagi anak berkebutuhan khusus terdiri dari jenjang TKLB, SDLB, SMPLB, SMALB, SMLB (Mangunsong, 1998). Jenis pendidikan Luar Biasa tersebut meliputi: SLB-A bagi peserta didik Tunanetra, SMPLB-B bagi peserta didik Tunarungu, SLB-C bagi peserta didik Tunagrahita, SLB-D bagi peserta didik Tunadaksa, SLB-E bagi peserta didik Tuna Laras, dan SLB-G bagi peserta didik Tuna Ganda. Disamping itu, pada saat ini telah berkembang pula sekolah untuk anak autis.Pada dasarnya guru yang mengajar di sekolah tersebut memang belum ada pendidikan khusus mengajar SLB oleh sebab itu guru juga menjadi penghambat siswa dalam proses pembelajaran matematika. Pada kenyataannya Penyebab penting lainnya kesulitan matematika pada siswa tersebut mungkin tidak ada kecocokan antara karakteristik pembelajaran, karakteristik masing-masing siswa dan instruksi yang mereka terima sehingga pada saat proses pembelajaran mereka tidak menerima dengan baik proses belajar dan tidak ada perbedaan antara proses belajar anak normal dan anak 
Vol 1 No 22020 Desember 2020

Jurnal AlphaEuclidEdu

berkebutuhan khusus meskipun sadar bahwa tidak adanya perbedaan dalam proses belajar namun dari pihak guru belum ada program untuk mengubah cara belajar yang seharusnya berbeda dengan anak pada umumnya, dalam kasus khusus seperti ini, instruksi harus disesuaikan dengan kebutuhan siswa. Selain itu, semua siswa dengan kesulitan matematika harusnya memerlukan spesifikasi Perhatian khusus.

Mengajar matematika dalam proses pembelajaran bukan hanya melibatkan guru/pengajar melinkan siswa yang secara langsung juga diperlukan faktor dukungan yang lain diantaranya: materi pelajaran yang layak, metode yang digunakan sesuai dengan standar, dan keadaan serta tempat proses pembelajaran yang mendukung. Pendidikan bagi anak berkebutuhan khusus banyak membawa manfaat bagi anak itu sendiri. Melalui pendidikan dapat mengetahui kemampuan yang dimiliki anak berkebutuhan khusus seterusnya akan dikembangkan yang akan berguna bagi kehidupannya karena banyak anak berkebutuhan khusus yang memiliki bakat yang tidak dimiliki oleh anak normal pada umumnya. Dapat menjadikan anak lebih disiplin dan mandiri sehingga tidak lagi bergantung pada orang lain dalam menjalani kehidupannya. Anak dapat bersosialisasi dan berkomunikasi dengan masyarakat sekitar sehingga anak merasa menjadi bagian dari masyarakat tersebut. Dapat mewujudkan seseorang yang memiliki kehidupan yang lebih baik di masa yang akan datang. Untuk memperoleh berhasilnya proses pembelajaran matematika terhadap siswa SLB diperlukan sarana dan prasarana baik pokok maupun pembantu/pelengkap. Hal ini dikarenakan harus mempertimbangkan kondisi yang ada pada siswa tunarungu yang mencakup kondisi fisik, mental, emosi araupun sosialnya. Siswa SLB sangat memerlukan pelayanan serta pendidikan yang lebih. Perlu diketahui bahwa belum ditemukan metode atau pendekatan jenis pendidikan serta cara yang dapat diberikan dalam pelayanan pendidikan untuk semua masalah yang tidak sama. Iniah alasan kenapa para guru diharuskan agar tetap aktif dan kreatif untuk memberikan pendidikan yang terbaik bagi siswa SLB pada umumnya sehingga mampu mengembangkan strategi atau metode

Menurut Drawing on Herscovics (1989) Hambatan kognitif adalah hambatan yang dihadapi dalam proses akuisisi pengetahuan baru. Mallet (2013: 152) menulis bahwa hambatan kognitif adalah "situasi di mana struktur mental yang ada sesuai untuk satu domain tetapi menyebabkan hambatan belajar di domain lain karena ketidakcocokan dengan situasi atau konsep baru". Jadi, ketika siswa bertemu dengan pengetahuan baru, pengetahuan mereka sebelumnya mungkin tidak kompatibel dengan yang baru, mengakibatkan konflik kognitif antara keduanya (Tall \& Vinner, 1981; Tall, 1991). Banyak dari hambatan kognitif ini muncul sebagai konsekuensi dari proses abstraksi yang terlibat dalam formalisasi konsep. Sebagai contoh, penelitian telah mengidentifikasi perbedaan antara definisi formal dari konsep batas dan gambar yang digunakan peserta didik dalam pikiran mereka ketika mereka bekerja dengannya, sering mengakibatkan ketidakcocokan antara gambar konsep individu dan definisi formal (Parameswaran, 2007; Tinggi \& Vinner, 1981). Semakin abstrak konsepnya, semakin banyak kesulitan konseptual yang dialami siswa dan semakin sedikit mereka mampu 
Vol 1 No 22020 Desember 2020

Jurnal AlphaEuclidEdu

mengoordinasikan gambar konsep mereka dengan definisi konsep, menabur benih hambatan kognitif masa depan (Tall \& Schwarzenberger, 1978). Selain itu, seperti dibahas di atas, ketika disajikan dengan representasi simbolik dari batas, siswa sering menemukan membedakan antara proses menemukan batas dan nilai yang terkait dengan itu sulit (Kidron, 2008). Artinya, kegagalan melihat persamaan dan perbedaan antara keduanya memprovokasi hambatan kognitif. Secara umum, siswa cenderung memiliki pandangan proses dinamis tetapi tidak melihat objek statis batas, dengan konsekuensi bahwa mereka tidak dapat melihat interaksi antara keduanya (Bagni, 2005; Parameswaran, 2007; Williams, 1991). Juga, konsepsi spontan dan sebelumnya biasanya bertahan lama dalam pikiran siswa (Prezenioslo, 2004), menunjukkan bahwa konsepsi dan gambar yang terbentuk selama tahun sekolah menengah mereka dapat tetap bersama siswa melalui formalisasi yang diperkenalkan di universitas (Prezenioslo, 2004) dan bertahan bahkan di luar instruksi universitas yang dirancang untuk membantu siswa mengatasi kesulitan seperti itu (Szydlik, 2000). Dengan demikian, sifat abstrak dari konsep batas dan proses abstraksi terlibat di dalamnya 4 formalisasi, inkompatibilitas antara konsep gambar dan definisi konsep, batas yang diperoleh, pengetahuan sebelumnya terkait dengan konsep batas dan kata-kata yang terkait semua, sumber hambatan kognitif.

\section{Metode Penelitian}

Metode yang dipandang sesuai dalam penelitian ini adalah menggunakan metode deskriptif karena sesuai dengan permasalah yang akan dikaji, dikarenakan tujuan dari penelitian ini untuk mengetahui faktor kognitif penyebab tantangan belajar matematika materi Aritmatika Sosial pada peserta didik anak berkebutuhan khusus Kelas VIII di SMPLB-B Dharma Asih Pontianak. Studi kasus adalah bentuk penelitian yang digunakan dalam penelitian ini. Subjek penelitian ini yaitu 4 siswa kelas VIII Sekolah Menengah Pertama Luar Biasa - B Dharma Asih Pontianak. Dalam penelitian ini prosedur penelitian terdiri atas 3 tahap yaitu tahap persiapan, tahap pelaksanaan, dan tahap pembuatan laporan. Alat pengumpulan data yang digunakan pada penelitian ini adalah berupa tes tertulis berbentuk esay dan wawancara mendalam. Teknik analisis data dilakukan berdasarkan pada rumusan masalah yang dijawab. Dalam penelitian ini, peneliti ingin mengetahui dan mendapatkan informasi mengenai tantangan belajar matematika dalam materi Aritmatika Sosial pada anak berkebutuhaan khusus kelas VIII di SMPLB-B Dharma Asih Pontianak

\section{Hasil Penelitian dan Pembahasan}

\subsection{Hasil Penelitian}

Hasil penelitian yang sudah peneliti lakukan, didapat data yang dibutuhkan untuk mendeskripsikan tantangan belajar matematika pada anak berkebutuhan khusus yang meliputi hasil deskripsi data, analisis data tes, dan analisis data wawancara tantangan belajar matematika dalam materi aritmatika sosial pada anak berkebutuhan khusus. 
Vol 1 No 22020 Desember 2020

Jurnal AlphaEuclidEdu

Penelitian ini dilakukan dengan maksud untuk mengetahui tantangan belajar matematika pada anak berkebutuhan khusus pada materi aritmatika sosial yang melibatkan siswa pada tes tantangan belajar matematika. Dengan indikator yang hendak dicapai dalam pembelajaran yaitu dapat menentukan dan menyelesaikan masalah yang terkait denan dengan materi aritmatika sosial dalam kehidupan sehari-hari.

Pada awal pembelajaran, guru memberikan salam yang tertuju ke peserta didik dan menyuruh peserta didik untuk mempersiapkan alat tulis diatas meja. Kemudian guru menjelaskan materi aritmatika sosial sesuai dengan soal yang akan diberi peneliti. Selanjutnya guru memberikan contoh cara menentuan hasil untung rugi dalam penerapan sehari-hari. Pendidik memberikan contoh soal cerita, peserta didik diminta mencatat soal dibuku terlebih dahulu.peserta didik diajak bersama-sama mengerjakan contoh soal yang diberikan guru, setelah selesai menjelaskan soal pertama, guru memberikan contoh soal yang serupa dengan sebelumnya dan guru meminta peserta didik $\mathrm{AB}$ untuk mengerjakannya. $\mathrm{AB}$ tidak ada mengalami kesulitan dalam mengerjakan soal tersebut hanya saja VR sulit untuk menjelaskan cara penyelesaiannya. Selanjutnya mengerjakan soal kedua guru meminta VR untuk mengerjakan soal tersebut. VR mendapatkan hasil pengurangan dengan benar dan tepat tetapi sulit untuk menjelaskan kembali penyelesaiannya. Untuk soal ketiga guru melemparkan soal ke peserta didik SS, tetapi SS mengalami kesulitan dalam mengerjakan soal ketiga sehingga guru melemparkan pertanyaan ke peserta didik yang lain. Setelah ketiga soal selesai dikerjakan, guru meminta peserta didik untuk menulis kembali jawaban yang ada dipapan tulis.

Berdasarkan hasil pengamatan, peserta didik kurang aktif atau bahkan tidak ada yang mau beertanya kepada guru jika mengalami kesulitan belajar. Ketika guru bertanya, peserta didik VR aktif menjawab pertanyaan guru meskipun mengalami hambatan dalam wicara. Untuk peserta SS, terlihat sangat jelas bahwa peserta didik tersebut sama sekali tidak dapat menerima pembelajaran dengan baik. Dari 4 peserta didik, 3 peserta didik belum mencapai KKM yaitu 65 . Jadi $75 \%$ peserta didik belum mencapai KKM dan mengalami hambatan belajar. Berdasarkan klasifikasi tersebut, peneliti memilih 3 subjek terpilih langkah selanjutnya adalah mendeskripsi jawaban hasil penyelesaian soal

Tabel 1. Skor dan Nilai Tes Tantangan Belajar Matematika Pada Anak Berkebutuhan Khusus

\begin{tabular}{|c|c|c|c|c|c|c|c|}
\hline \multirow{2}{*}{ No } & \multirow{2}{*}{$\begin{array}{l}\text { Kode } \\
\text { Nama }\end{array}$} & \multicolumn{3}{|c|}{ Skor setiap soal } & \multirow{2}{*}{$\begin{array}{l}\text { Jumlah } \\
\text { Skor }\end{array}$} & \multirow{2}{*}{ Nilai } & \multirow{2}{*}{ Kriteria } \\
\hline & & 1 & 2 & 3 & & & \\
\hline 1 & VR & 9 & 4 & 3 & 18 & 80 & Tuntas \\
\hline 2 & $\mathrm{AB}$ & 5 & 3 & 2 & 11 & 50 & $\begin{array}{l}\text { Belum } \\
\text { Tuntas }\end{array}$ \\
\hline 3 & HRS & 4 & 4 & 1 & 10 & 45 & $\begin{array}{l}\text { Belum } \\
\text { Tuntas }\end{array}$ \\
\hline 4 & SS & 4 & 4 & 2 & 11 & 50 & $\begin{array}{l}\text { Belum } \\
\text { Tuntas }\end{array}$ \\
\hline
\end{tabular}


Vol 1 No 22020 Desember 2020

Jurnal AlphaEuclidEdu

\subsection{Pembahasan}

Berdasarkan hasil analisa data yang telah dipaparkan pada hasil penelitian, akan dilakukan pembahasan lebih lanjut terhadap data-data tersebut. untuk mengetahui faktor kognitif apakah yang menjadi tantangan belajar matematika dalam materi aritmatika sosial pada anak berkebutuhan khusus di SMPLB-B Dharma Asih Pontianak merupakan tujuan dari penelitian ini. Berikut ini akan dipaparkan mengenai bagaimana mengetahui faktor kognitif yang menjadi tantangan belajar matematika dalam materi aritmatika sosial.

Subjek VR pada soal nomor 1 bagian a, subjek VR sudah menjawab dengan benar dan pada bagian $b$ VR juga menjawab hasil akhir dengan benar namun VR tidak menuliskan rumus. Pada soal nomor 2 VR menjawab kurang tepat karena salah menuliskan rumus. Pada soal nomor 3 VR tidak bisa mengerjakan penyelesaiannya namun VR sudah menuliskan nilai diketahui dan ditanya dengan benar. Berdasarkan hasil wawancara, tampak bahwa subjek mengalami hambatan dalam mengerjakan soal dikarenakan subjek kurang teliti dalam mengerjakan soal. Kemudian subjek tidak mengerti isi soal menggunakan bruto, netto dan tara, hal ini menunjukan bahwa VR memang mengalami hambatan dalam soal cerita. Penyebab tersebut adalah kurangnya pemahaman VR tentang kalimat matematika dan dari pihak guru jarang memberikan soal dalam bentuk cerita. Dari hasil tes dan wawancara dapat disimpulkan bahwa tantangan belajar matematika pada kognitif 1 subjek VR yaitu daya ingat yang lemah membuat subjek lambat untuk mencapai hasil yang diharapkan, kemudian pada kognitif 2 subjek VR belum memahami konsep dasar materi arimatika sosial dan lambatnya menangkap materi yang dijelaskan, sehingga membuat subjek merasa kesulitan dalam menentukan hasil akhir, yang terakhir pada kognitif 3 subjek VR belum mampu menerapkan materi yang dipaparkan dikarenakan kurangnya latihan yang diberikan guru sehingga subjek belum mampu mengaplikasikan penyelesaian suatu masalah matematika yang diberikan.

Subjek AB Pada soal nomor 1 bagian a Subjek AB sudah menjawab dengan benar namun pada bagian b subjek $\mathrm{AB}$ belum tepat dalam menyelesaikan soal. Pada soal nomor $2 \mathrm{AB}$ menjawab kurang tepat namun $\mathrm{AB}$ sudah dapat menentukan nilai yang diketahui dan yang ditanyakan pada soal. Untuk soal nomor 3 AB tidak dapat menentukan dan menyimpulkan hasil dengan benar belum bisa menyelesaikan model matematika sesuai dengan prosedur dengan tepat tetapi dapat menuliskan apa yang diketahui dan ditanya dengan benar. Berdasarkan wawancara peneliti, tampak subjek tidak mengerti isi soal menggunakan bruto, netto dan tara. Kemudian peneliti menjelaskan kembali kepada $\mathrm{AB}$ bagaimana cara menentukan tara dalam soal cerita tersebut. Hal ini menunjukan bahwa $\mathrm{AB}$ memang mengalami hambatan dalam soal cerita. Penyebab tersebut adalah kurangnya pemahaman AB tentang kalimat matematika dan dari pihak guru jarang memberikan soal dalam bentuk cerita. AB juga mengalami hambatan pada soal nomor $1 \mathrm{~b}$ sehingga peneliti meminta $A B$ untuk membaca dan mengerjakan kembali soal tes nomor $1 \mathrm{~b}$. Berdasarkan hasil wawancara, tampak bahwa 
Vol 1 No 22020 Desember 2020

Jurnal AlphaEuclidEdu

subjek mengalami hambatan dalam mengerjakan soal dikarenakan subjek kurang teliti dalam mengerjakan soal. Dari hasil tes dan wawancara dapat disimpulkan bahwa tantangan belajar matematika pada kognitif 1 subjek $\mathrm{AB}$ yaitu kemampuan mengingat yang lemah membuat subjek lambat untuk mencapai hasil yang diharapkan, kemudian pada kognitif 2 subjek AB mampu memahami konsep dasar materi arimatika sosial dan walaupun lambat menangkap materi yang dijelaskan, sehingga membuat subjek mampu menentukan hasil akhir, yang terakhir pada kognitif 3 subjek $A B$ belum mampu menerapkan materi yang dipaparkan dikarenakan kurangnya latihan yang diberikan guru sehingga subjek belum mampu mengaplikasikan penyelesaian suatu masalah matematika yang diberikan.

Subjek HRS Pada soal nomor 1 bagian a subjek HRS sudah benar menjawab dengan benar namun pada bagian b subjek HRS belum tepat dalam menyelesaikan soal. Pada soal nomor 2 HRS menjawab kurang tepat namun HRS sudah menentukan nilai diketahui serta yang ditanaya pada soal. Pada soal nomor 3 HRS belum dapat menyelesaikan konsep matematika sesuai dengan prosedur soal dengan tepat namun HRS dapat menentukan nilai diketahui dan ditanya dengan tepat. Berdasarkan hasil wawancara, tampak bahwa subjek mengalami hambatan dalam operasi pengurangan. Dalam wawancara, peneliti menjelaskan kepada HRS bagaimana cara menyelesaikan operasi pengurangan menggunakan metode jual beli. Ketika peneliti menanyakan apakah harga beli lebih tinggi atau rendah dari harga jual, HRS menjawab dengan cara menebak. Hal ini menunjukan bahwa HRS memang kurang memahami operasi pengurangan menggunakan metode jual beli. Dari hasil tes dan wawancara dapat disimpulkan bahwa tantangan belajar matematika pada kognitif 1 subjek HRS yaitu daya ingat yang lemah membuat subjek lambat untuk mencapai hasil yang diharapkan, kemudian pada kognitif 2 subjek HRS belum memahami konsep dasar materi arimatika sosial dan lambatnya menangkap materi yang dijelaskan, sehingga membuat subjek merasa kesulitan dalam menentukan hasil akhir, yang terakhir pada kognitif 3 subjek HRS belum mampu menerapkan materi yang dipaparkan dikarenakan kurangnya latihan yang diberikan guru sehingga subjek belum mampu mengaplikasikan penyelesaian suatu masalah matematika yang diberikan.

Subjek SS Pada soal 1 bagian a subjek SS sudah menjawab dengan benar namun pada bagian b subjek SS belum dapat memberikan jawaban dengan benar. Pada soal nomor 2 subjek SS belum tepat memberikan hasil akhir namun sudah menajwab dengan benar nilai diketahui dan ditanya serta konsep matematika yang benar. Pada soal nomor 3 subjek SS hanya dapat menuliskan nilai diketahui dan ditanya namun tidak dapat menyelesaikan konsep matematika sesuai prosedur dan tidak dapat menjawab hasil akhir. Berdasarkan hasil wawancara diatas, terlihat bahwa subjek masih belum paham dengan konsep matematika sehingga SS mengalami hambatan dalam menyelesaikan hasil akhir.

Dari hasil tes dan wawancara dapat disimpulkan bahwa tantangan belajar matematika pada kognitif 1 subjek SS yaitu daya ingat yang lemah membuat subjek 
Vol 1 No 22020 Desember 2020

Jurnal AlphaEuclidEdu

belum mampu mencapai hasil yang diharapkan, kemudian pada kognitif 2 subjek SS belum memahami konsep dasar materi arimatika sosial dan lambatnya menangkap materi yang dijelaskan, sehingga membuat subjek merasa kesulitan dalam menentukan hasil akhir, yang terakhir pada kognitif 3 subjek SS belum mampu menerapkan materi yang dipaparkan dikarenakan kurangnya latihan yang diberikan guru sehingga subjek belum mampu mengaplikasikan penyelesaian suatu masalah matematika yang diberikan. Jadi berdasarkan tes soal dan wawancara peneliti dengan subjek VR, AB, HRS, dan SS dapat disimpulkan bahwa faktor kognitif yang menjadi penyebab tantangan belajar matematika yang lebih dominan memepengaruhi ketiga subjek tersebut adalah pemahaman dan penerapan.

Faktor-faktor tersebut menjadi penyebab tantangan belajar siswa, siswa sangat sulit untuk mengingat materi yang telah dipelajari, sehingga guru harus mengulang materi yang telah diajarkan, kemudian dalam memahami isi soal perlu waktu lama karena daya tangkap yang lambat membuat siswa lambat dalam berfikir selain itu pengetahuan konsep dasar materi bilangan bulat yang membuat siswa sulit untuk memahami materi aritmatika sosial. Hal ini menunjukan bahwa pembelajaran matematika yang dialami siswa selama ini tidak bermakna. Menurut Ausubel (Dahar, 1996:112) pembelajaran bermakna merupakan suatu proses mengaitkan informasi baru pada konsep-konsep relevan yang terdapat dalam struktur kognitif seseorang. Proses belajar tidak sekedar menghafal konsep-konsep dan fakta-fakta belaka, namun berusaha menghubungkan konsep-konsep tersebut untuk menghasilkan pengetahuan, pemahaman, dan penerapan. Faktor kognitif yang dialami pada siswa sudah sepatutnya dijadikan bahan refleksi bagi guru untuk memperbaiki proses pembelajaran berikutnya, dalam memperbaiki proses pembelajaran matematika tentunya terkait dengan kebutuhan siswa yang didalamnya termuat potensi yang mereka miliki.

\section{Kesimpulan}

Dari hasil dan pembahasan Penelitian ini dapat disimpulkan faktor kognitif yang menjadi penyebab tantangan belajar matematika dalam materi aritmatika sosial pada peserta didik berkebutuhan khusus, yaitu: (1) faktor pengetahuan, lemahnya daya ingat siswa membuat guru harus mengulang lagi materi yang sudah diajarkan; (2) faktor pemahaman, dalam memahami isi soal perlu waktu lama karena daya tangkap yang lambat membuat siswa lambat dalam berfikir; (3) faktor penerapan, ketidakmampuan menerima perubahan soal lama ke soal baru membuat siswa sulit untuk mengaplikasikan penyelesaian dengan cara yang berbeda

\section{Referensi}

Barbara, Arikunto, Suharsimi. 2010. Prosedur Penelitian Suatu Pendekatan Praktik. Jakarta: Rineka Cipta.

Cornu, B. (1991). Limit In 30/05/2012.O. Tall (Ed), Advanced Mathematical Thinking (pp. 153-166). Dordrecht : Kluwer Academic Publisher 
Vol 1 No 22020 Desember 2020

Jurnal AlphaEuclidEdu

Calhoun, J. F. 1990. Psikologi tentang Penyesuaian dan Hubungan Kemanusiaan. (Terjemahan Ny. R. S. Satmoko). Semarang: IKIP Press.

Darmadi, Hamid. 2014. Metode Penelitian Pendidikan dan Sosial. Bandung: Alfabeta.

Depdiknas. (2005). Materi Pelatihan terintegrasi Matematika. Jakarta: Depdiknas Direktorat Jenderal Pendidikan dasar dan Menengah Direktorat Pendidikan Lanjutan Pertama.

riz Achmad Haryono. 2012. Statistik Psikologi (Online). (https://www.scribd.com/collections/3711378/Statistic-Psikologi), diakses 24 Juni 2019

Hallahan dan Kauffman (1982). Klasifikasi Ketunarunguan.

Jamila K.A. Muhammad. (2008) Special Education for Special Children. Bandung: Hikmah.

Kemendikbud, 2015, Pedoman Penilaian SDLB, SMPLB, SMALB, Jakarta : Kemendikbud RI

Kemendikbud. 2013. Matematika Kelas VIII SMP/MTs. Jakarta: Kementerian Pendidikan dan Kebudayaan Republik IndonesiaMillles \& Huberman. (1992). Analisis data kualitatif. Jakarta: UII Press.

Moores Donald F (1981). Education the deaf (Psychology principle and practices) HougtohbMiflin Company. Boston.

Moleng, Lexy J. 2013. Metode Penelitian Kualitatif Edisi Revisi. Bandung: PT. Remaja Rosdakaya.

Muhammad Soleh. (1998). Pokok-pokok pengajaran matematika sekolah. Jakarta: Pusat Perbukuan Bagian proyek Pengembangan Buku dan Minat Baca.

Mulyadi. (2010). Diagnosis Kesulitan Belajar \& Bimbingan terhadap Kesulitan Belajar Khusus. Yogyakarta: Nuha Litera.

Nazir, Moh. 2009. Metode Penelitian. Jakarta: Ghalia Indonesia.

NCTM. (2000). Principle and Standard for School Mathematics. Reston, Virginia: The National Council of Mathematics of Teacher of Mathematics, Inc.

Sugihartono, dkk. 2007. Psikologi Pendidikan. Yogyakarta: UNY Press.

Sugiyono, 2012. Memahami Penelitian Kualitatif. Bandung: Alfabeta.

Poerwandari, E. K. 1998. Pendekatan Kualitatif dalam Penelitian Psikologi. Jakarta: Lembaga Pengembangan Sarana dan Pendidikan Psikologi

Xin, Y. P., \& Jitendra, A. K. (1999). The effects of instruction in solving mathematical word problems for students with learning problems: A meta-analysis. The Journal of Special Eduation, 32, 207-225. 